\title{
Pengaruh Model TPS Berbantu Media Papontar Terhadap Hasil Belajar Dilihat dari Aktivitas Belajar Siswa
}

\author{
Risna Prasanti ${ }^{1}$, Djoko Purnomo ${ }^{2}$ \\ ${ }^{12}$ Proram Studi Pendidkan Guru Sekolah Dasar, Fakultas IImu Pendiikan \\ Universitas PGRI Semarang \\ e-mail: risnaprasani45@gmail.com
}

\begin{abstract}
Abstrak
Penelitian ini dilatar belakangi oleh rendahnya hasil belajar siswa pada pembelajaran tematik dan siswa masih kurang aktif dan berantusias dalam mengikuti pembelajaran serta masih rendahnya pemahaman tentang materi yang diajarkan oleh guru. Penelitian ini bertujuan untuk mengetahui adanya korelasi antara aktivitas belajar siswa dengan hasil belajar siswa serta untuk mengetahui adanya perbedaan antara siswa yang aktivitasnya tinggi dengan siswa yang aktivitasnya rendah. Metode penelitian yang digunakan yaitu penelitian experimen dengan pendekatan kuantitatif dengan desain One-Group pretest-posttest Design dengan bentuk Pre Experimental. Populasi dalam penelitian ini adalah seluruh siswa kelas IV SDN 05 Kabunan Pemalang Tahun Ajaran 2018/2019 yang berjumlah 30 siswa. Hasil penelitian menunjukkan bahwa terdapat korelasi antara aktivitas belajar siswa dengan hasil belajar siswa dengan model Think Pair Share (TPS) berbantu media papontar kelas IV SDN 05 Kabunan Pemalang dan berdasarkan uji regresi pengaruhnya sebesar $84,96 \%$, serta terdapat perbedaan rata-rata antara siswa yang aktivitasnya tinggi dengan siswa yang aktivitasnya rendah dengan dibuktikanya perhitungan hasil uji t diperoleh $t_{\text {tabel }}=2,048$ sedangkan $t_{\text {hitung }}=2,190$ dengan $t_{1}$ ${ }_{1 / 2} \alpha$ dengan taraf signifikan sebesar $5 \%$. Sehingga $t_{\text {hitung }}>t_{\text {tabel }}$ atau $2,190>2,048$. Hal ini menunjukkan bahwa model Think Pair Share (TPS) berbantu media papontar berpengaruh terhadap hasil belajar siswa dilihat dari aktivitasnya.
\end{abstract}

Kata Kunci: Model TPS berbantu media papontar, hasil belajar, aktivitas belajar

\begin{abstract}
This research is motivated by the low student learning outcomes in thematic learning and students are still less active and enthusiastic in participating in learning and the low understanding of the material taught by the teacher. This study aims to determine the correlation between student learning activities and student learning outcomes and to find out the differences between students whose activities are high with students whose activities are low. The research method used was experimental research with a quantitative approach with the design of One-Group pretest-posttest Design in the form of Pre Experimental. The population in this study were all fourth grade students of SDN 05 Kabunan Pemalang Academic Year 2018/2019 which amounted to 30 students. The results showed that there was a correlation between student learning activities and student learning outcomes with the Think Pair Share (TPS) model assisted by papontar media in grade IV SDN 05 Kabunan Pemalang and based on regression tests the effect was $84.96 \%$, and there were differences in average between students the activity is high with students whose activities are low with evidence that the calculation of the results of the $t$ test is obtained t table $=2.048$ while thitung $=2.190$ with $t 1-1$ / $2 \alpha$ with a significant level of $5 \%$. So that $t$ count $>t$ table or $2,190>2,048$. This shows that the Think Pair Share (TPS) model assisted by papontar media influences student learning outcomes seen from their activities.
\end{abstract}

Keywords: TPS model aided by papontar media, learning outcomes, learning activities 


\section{Pendahuluan}

Pendidikan adalah suatu proses yang berjalan terus menerus baik dari aspek kompetensi maupun aspek sosial. Pendididikan diwujudkan dengan adanya sekolah sebagai lembaga institusi untuk menyalurkan proses pendidikan. Sekolah didirikan dengan adanya tenaga kependidikan dan anak didik, masyarakat juga dalam hal ini menjadi bagian dari adanya sekolah.Dengan diselenggarakannya sekolah maka cita-cita bangsa indonesia yang tertulis dalam Pembukaan UUD Tahun 1945 yaitu mencerdaskan kehidupan bangsa dapat terwujud. Sehingga melalui pendidikan inilah dapat membentuk karakter yang baik dan memberikan keteladanan. Dalam UU RI No. 20 Tahun 2003 tentang Sistem Pendidikan Nasional menyatakan bahwa pendidikan diselenggarakan dengan memberi keteladanan, membangun kemauan, dan mengembangkan kreativitas peserta didik dalam proses pembelajaran (Bab III Pasal 4 ayat 4). Sekolah bukan hanya tempat untuk menyalurkan ilmu pengetahuan saja, tetapi juga untuk membentuk karakter, membimbing dan memberi contoh keteladanan yang baik kepada siswa. Guru juga ikut membantu dalam proses pembelajaran agar siswa mampu mengembangkan kreativitas yang dimiliki.

Pendidikan adalah hal terpenting bagi setiap negara untuk dapat berkembang pesat. Negara yang hebat akan menempatkan pendidikan sebagai prioritas pertamanya, karena dengan pendidikan, kemiskinan pada rakyat di negara tersebut akan dapat tergantikan menjadi kesejahteraan. Bagaimanapun, dalam perkembangannya, pendidikan di Indonesia senantiasa harus menghadapi beberapa masalah di setiap tahapnya. Masalahmasalah tersebut hanya dapat diselesaikan dengan partisipasi dari semua pihak yang terkait di dalam sistem pendidikan, seperti orangtua, guru-guru, kepala sekolah, masyarakat, dan juga peserta didik itu sendiri. Pada fase input, orangtua memiliki kontribusi besar dalam memperkenalkan nilai-nilai baik kepada anak-anak mereka. Orangtua bertanggung jawab penuh untuk mendidik anak-anak mereka dengan nilai-nilai kepemimpinan, sehingga mereka mempunyai bekal yang cukup untuk menjadi cikal bakal pemimpin ketika mereka mulai memasuki institusi formal, seperti sekolah (Megawati, 2012).

Peningkatan kualitas pendidikan merupakan agenda besar pendidikan di Indonesia. Dalam rangka mewujudkan pendidikan yang bermutu tentu tidak terlepas dari peranan berbagai pihak, salah satunya adalah peran tenaga kependidikan. Hamalik (2003 : 9) tenaga kependidikan merupakan suatu komponen yang penting dalam penyelenggaraan pendidikan, yang bertugas menyelenggarakan kegiatan mengajar, melatih, meneliti, mengembangkan, mengelola dan memberikan pelayanan teknis dalam bidang kependidikan (Anggia, 2015).

Pembelajaran pada dasarnya usaha sadar yang dilakukan seorang guru untuk mengarahkan, membelajarkan dan membimbing siswanya dengan sumber belajar untuk mencapai tujuan yang diharapkan. Pembelajaran yang menyenangkan dapat menjadikan siswa belajar dengan semangat dan termotivasi. Untuk itu perlu adanya inovasi dalam pembelajaran. Inovasi dalam pembelajaran bisa dilakukan oleh guru sebagai implementasi dari kurikulum 13 baik dari metode, model maupun penggunaan media. Karena kurikulum 13 adalah pembelajaran yang menjadikan siswa itu untuk aktif dalam proses pembelajaran sehingga guru harus menerapkan pembelajaran yang kreatif, inovatif dan menyenangkan, yang menjadikan siswa menjadi aktif selama proses pembelajaran.

Guru menjadi faktor yang menentukan mutu pendidikan karena guru berhadapan langsung dengan para peserta didik dalam proses pembelajaran di kelas. Di tangan guru, mutu dan kepribadian peserta didik dibentuk. Karena itu, perlu sosok guru kompeten, bertanggung jawab, terampil, dan berdedikasi tinggi. Guru adalah kurikulum berjalan. Sebaik apa kurikulum dan sistem pendidikan yang ada tanpa didukung oleh kemampuan guru, semuanya akan siasia. Guru berkompeten dan bertanggung jawab, utamanya dalam mengawal perkembangan peserta didik sampai ke suatu titik maksimal. Tujuan akhir seluruh proses pendampingan guru adalah tumbuhnya pribadi dewasa yang utuh (Shabir, 2015).

Implementasi dalam kuriulum 13 pembelajaran di sekolah dasar dikemas dalam pembelajaran tematik. Daryanto (2014:3) mengatakan bahwa "pembelajaran tematik diartikan sebagai pembelajaran yang menggunakan tema untuk mengaitkan beberapa mata pelajaran sehingga dapat memberikan pengalaman bermakna kepada siswa". Dengan adanya pembelajaran tematik ini siswa bukan hanya belajar sekedar teori saja di kelas tetapi bisa dilakukan di luar kelas sehingga siswa belajar dengan lingkungan yang dapat memperoleh pengalaman bermakna bagi siswa.

Pembelajaran tematik dikatakan berhasil apabila pembelajaran yang diajarkan guru kepada siswa memberikan kesan bermakna karena pembelajaran tematik ini siswa terlibat 
secara aktif dan guru hanya sebagai fasilitator yang membimbing siswa untuk dapat belajar berdasarkan pengalaman mereka. Sehingga sebisa mungkin guru dalam memberikan pembelajaran itu dapat berkreatif dalam menentukan model, metode penggunaan media sehingga siswa akan merasa senang dan tidak membosankan.

Menurut Arsyad (2016 : 10) dalam bukunya mengatakan bahwa "media pembelajaran adalah segala sesuatu yang dapat digunakan untuk menyampaikan pesan atau informasi dalam proses belajar mengajar sehingga dapat merangsang perhatian dan minat siswa dalam belajar". Dengan kata lain media pembelajaran adalah segala sesuatu yang dapat digunakan untuk membantu guru dalam menyampaikan pesan dari suatu materi yang dapat membantu pemahaman siswa. Media yang digunakan peneliti sebagai penelitian yaitu media papontar (papan pohon pintar) yang merupakan media visual yang memiliki fungsi sebagai penyampain pesan kepada siswa sekaligus membantu guru dalam menciptakan suasana pembelajaran yang menyenangkan sambil bermain.

Sehingga tidak hanya media pembelajaran saja tetapi model pembelajaran juga bisa digunakan untuk menciptakan suasana belajar yang menyenangkan bagi siswa. Menurut Ertikanto (2016 : 186) dalam bukunya mengemukakan bahwa "model pembelajaran Think Pair share (TPS) merupakan salah satu model pembelajaran kooperatif yang mampu mengubah asumsi bahwa metode resitasi dan diskusi perlu diselenggarakan dalam setting kelompok secara keseluruhan".

Menurut Miftahul Huda (dalam jurnal Susanti, 2017 : 3) "Think Pair Share (TPS) merupakan strategi yang memperkenalkan gagasan tentang waktu 'tunggu atau berpikir' pada elemen interaksi pembelajaran kooperatif yang saat ini menjadi salah satu faktor ampuh dalam meningkatkan respons siswa terhadap pertanyaan" Model Think Pair Share (TPS) peneliti pilih sebagai model yang akan digunakan sebagai penelitian.

Menurut Susanto (2016:5) mengatakan bahwa "hasil belajar adalah perubahanperubahan yang terjadi pada diri siswa, baik yang menyangkut aspek kognitif, afektif, dan psikomotor sebagai hasil dari kegiatan belajar".

Menurut Dimyati dan Mudjiono (2006) dalam bukunya Parwati, dkk (2018:24) mengatakan bahwa "hasil belajar sebagai suatu interaksi antara pembelajar dan tindkaan mengajar".

Dari beberapa pendapat ahli diatas mengenai hasil belajar dapat disimpulkan bahwa hasil belajar adalah suatu perubahan tingkah laku atau perbuatan pada diri individu yang dihasilkan dari proses belajar baik afektif, kognitif maupun psikomotorik.

Menurut Sardiman (2014:95) dalam bukunya mengatakan bahwa "Aktivitas diperlukan dalam belajar karena pada dasarnya belajar adalah berbuat. Siswa sebagai subjek harus aktif berbuat sehingga dalam belajar perlu adanya aktivitas karena tanpa aktivitas proses belajar tidak mungkin berlangsung dengan baik".

Menurut Apriliawati (dalam jurnal Mufidah, 2013 : 1) mengemukakan bahwa "aktivitas belajar adalah kegitan yang dilakukan siswa selama proses pembelajaran. Aktivitas siswa selama pembelajaran mencerminkan adanya motivasi ataupun keinginan siswa untuk belajar".

Dari pendapat beberapa ahli diatas dapat disimpulkan bahwa aktivitas belajar adalah segala sesuatu yang berkaitan dengan proses belajar siswa yang melibatkan kemampuan psikomotor dan afektif, sehingga belajar tanpa adanya aktivitas itu dirasa kurang efektif karena aktivitas itu selalu ada dalam setiap pembelajaran.

Pembelajaran yang dilakukan di SDN 05 Kabunan Kabupaten Pemalang, masih bersifat konvensional. Guru masih minim dalam menggunakan model pembelajaran yang menarik sehingga pembelajaran lebih terkesan monoton dan membosankan, siswa hanya mengikuti pembelajaran yang diberikan oleh guru saja. Hanya sebagian siswa yang aktif dalam menjawab tanya jawab yang diberikan guru. Guru juga masih minim dalam penggunaan media pembelajaran karena keterbatasan. Sehingga pembelajaran kurang menarik perhatian siswa. Pembelajaran lebih didominasi dengan metode ceramah, dan siswa hanya menerima apa yang diberikan oleh guru. Sehingga perlu adanya upaya untuk menarik minat siswa dalam pembelajaran dan mengubah pembelajaran supaya berkesan lebih menarik dan bermakna.

Hasil belajar siswa sangatlah penting, sebagai penunjang seberapa siswa tersebut berhasil dalam mengikuti pembelajaran. Oleh sebab itu, penggunaan metode, model dan media pembelajaran sangatlah penting dalam pembelajaran supaya hasil belajar siswa secara kognitif baik. Hal ini diperkuat dengan hasil penelitian yang relevan berkaitan dengan pembelajaran menggunakan model yang dapat meningkatkan hasil belajar siswa yaitu penelitian yang telah dilakukan oleh Theana pada tahun 2017 dengan judul penelitian "Keefektifan Model Pemelajaran Time Token Terhadap Hasil Belajar Subtema Keseimbangan Ekosistem Siwa 
Kelas V SD". Berdasarkan hasil penelitian tersebut dapat dismpulkan bahwa model yang digunakan sangat berpengaruh terhadap hasil belajar.

Dari rata-rata hasil belajar siswa kelas IV SDN 05 Kabunan Pemalang untuk pembelajaran tematik masih 65\% yang berhasil mencapai KKM sedangkan 35\% masih dibawah angka KKM. KKM yang ditetapkan yaitu 70. Selain masalah hasil belajar, kurangnya komunikasi dan kerjasama antar siswa juga masih rendah. Dikarenakan kurang dalam penggunaan model pembelajaran sehingga siswa dalam berkelompok masih kurang maksimal dalam bekerjasama.

Sehubungan dengan permasalahan tersebut peneliti akan memberikan perlakuan kepada kelas IV SDN 05 Kabunan Kabupaten Pemalang yaitu dengan menggunakan model pembelajaran Think Pair Share (TPS) berbantu media papontar. Dengan menggunakan model dan media tersebut diharapkan mampu untuk menjadikan semangat dan antusias belajar siswa menjadi tinggi serta siswa dapat aktif dengan adanya media papontar dan mampu bekerja sama dalam bertukar pikir dengan teman yang lainnya serta dapat meningkatkan akivitas siswa dalam kemampuan pskomotor.

Tujuan dalam penelitian ini adalah untuk mengetahui untuk mengetahui korelasi antara aktivitas belajar siswa setelah mendapat pembelajaran dengan model pembelajaran Think Pair Share (TPS) berbantu media papontar terhadap hasil belajar siswa dan untuk mengetahui adanya perbedaan hasil belajar siswa ditinjau dari siswa yang aktivitasnya tinggi dan siswa yang aktivitasnya rendah setelah mendapat model pembelajaran Think Pair Share (TPS) berbantu media papontar.

\section{Metode}

Penelitian dilaksanakan di SDN 05 Kabunan Kecamatan Taman Kabupaten Pemalang, yang terletak di jalan Wora-wari I No.058, Kecamatan Taman Kabupaten Pemalang. Waktu penelitian ini dilakukan pada semester Genap Tahun Ajaran 2018/2019. Pada bulan september melakukan observasi dan wawancara dan pada tanggal 14-18 Mei 2019 melakukan penelitian di lapangan.

Sugiyono (2016 : 38) "Variabel penelitian adalah segala sesuatu yang berbentuk apa saja yang ditetapkan oleh penelitian untuk dipelajari dan kemudian ditarik kesimpulannya".

Sugiyono (2016 : 39) dalam bukunya mengatakan "Variabel bebas adalah variabel yang mempengaruhi atau yang menjadi sebab perubahannya atau timbulnya variabel independen (terikat)". Dalam penelitian ini variabel bebasnya (X) adalah model pembelajaran Think Pair Share (TPS) berbantu media papontar. "Variabel terikat adalah yang dipengaruhi atau yang menjadi akibat, karena adanya variabel bebas". Dalam penelitian ini variabel terikatnya ( $\mathrm{Y}$ ) adalah hasil belajar siswa dilihat dari aktivitas belajar pada tema dareah tempat tinggalku subtema lingkungan tempat tinggalku kelas IV SDN 05 Kabunan.

Menurut Sugiyono (2016: 2) metode penelitian merupakan cara ilmiah untuk mendapatkan data dengan tujuan dan kegunaan tertentu. Jenis penelitian ini adalah kuantitatif. Pada penelitian ini desain yang digunakan adalah One-Group pretest-posttest Design dengan bentuk Pre Experimental. Penelitian ini tidak menggunakan kelas pembanding tetapi digunakan tes awal atau pretest sehingga pemberian perlakuan dapat diketahui dengan jelas.

Populasi yang diambil dalam penelitian ini adalah seluruh siswa kelas IV SDN 05 Kabunan Kabupaten Pemalang yang berjumlah 30 siswa. Sampel adalah sebagian atau wakil populasi yang diteliti. (Arikunto, $2010: 174$ ). Berdasarkan penjelasan tersebut maka sampel yang digunakan dalam penelitian ini adalah seluruh siswa kelas IV SDN 05 Kabunan Kabupaten Pemalang yang berjumlah 30 siswa.

Teknik sampling yang digunakan adalah Nonprobability Sampling berbentuk sampling jenuh. Jadi dalam penelitian ini jumlah sampel yang digunakan adalah semua anggota populasi yang dijadikan sampel yaitu berjumlah 30 siswa kelas IV SDN 05 Kabunan Kabupaten Pemalang. Teknik pengumpulan data yang digunakan dalam penelitian ini yaitu observasi, wawancara, tes dan dokumentasi.

Observasi dalam penelitian ini digunakan untuk mengetahui dan mengamati aktivitas siswa dan guru dalam proses pembelajaran, sehingga dapat membantu penelitian. Observasi ini dilakukan secara langsung pada saat proses pembelajaran berlangsung untuk memperoleh data dengan mengamati dan mencatat informasi yang didapatkan sebelum dilakukannya penelitian dan pada saat penelitian berlangsung selama lima hari mengamati dan mencatat aktivitas siswa dengan lembar observasi.

Wawancara yang dilakukan peneliti dengan guru kelas IV karena ingin mengetahui permasalahan pembelajaran yang dialami oleh guru kelas IV terlebih pada pembelajaran 
tematik. Dalam penelitian ini menggunakan wawancara tidak terstruktur yang dilakukan sebelum penelitian.

Tes yang digunakan dalam penelitian ini adalah tes hasil belajar yang digunakan untuk mengukur aspek kognitif siswa serta pencapaian siswa setelah mempelajari materi yang disamapaikan guru berupa pertanyaan atau latihan soal. Tes yang diberikan petest yang dilakukan sebelum diberi perlakuan dan posttest setelah diberikan perlakuan. Metode dokumentasi ini digunakan untuk memperoleh data-data siswa yang meliputi daftar nama siswa, jumlah siswa dan presensi. Selain itu metode dokumentasi ini dilakukan dengan cara mengambil foto pada saat proses pembelajaran berlangsung.

Teknik analisis instrumen penelitian meliputi uji validitas, reliabilitas, taraf kesukaran dan daya pembeda. Yang sebelum melakukan penelitian peneliti melakukan uji coba terlebih dahulu. Kemudian untuk teknik analisis data awal menggunakan uji normalitas dan uji homogenitas, sedangkan analisis data akhir menggunakan uji normalitas akhir, uji homogenitas varian akhir, uji korelasi dan regresi, dan uji t serta ketuntasan belajar individu dan klasikal.

\section{Hasil dan Pembahasan}

Dalam penelitian ini dilakukannya dua pengambilan data yaitu pretest dilakukan sebelum diberi perlakuan dan posttest dilakukan sesudah diberi perlakuan. Hasil dari nilai pretest menunjukan 9 siswa yang tuntas dan 21 siswa lainnya belum tuntas dengan rata-rata 61,33\%. Setelah diberikan adanya perlakuan dengan model Think Pair Share (TPS) berbantu media papontar hasil belajar siswa meningkat, dengan dibuktikannya hasil postest yaitu 23 siswa tuntas mencapai KKM dan 7 siswa yang masih belum tuntas dengan rata-rata 78,93\%. Hal ini bisa dikatakan model pembelajran Think Pair Share (TPS) berbantu media papontar berhasil. Untuk lebih jelasnya bisa dilihat pada gambar diagram batang pretest dan postest berikut ini :

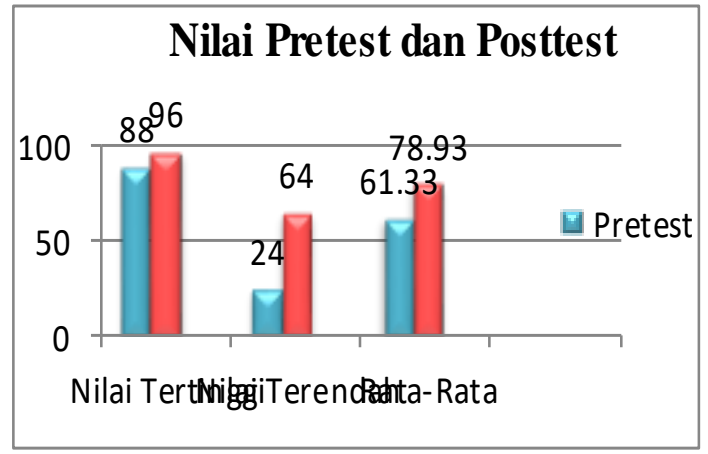

Gambar 1. Diagram Pretest dan posttest

Untuk mengukur kemampuan psikomotor siswa yaitu dalam hal ini aktivitas belajar siswa menggunakan lembar observasi yang dinilai selama pembelajaran berlangsung yaitu peneliti melakukannya selama 5 hari. Berikut hasil diagram aktivitas belajar siswa :

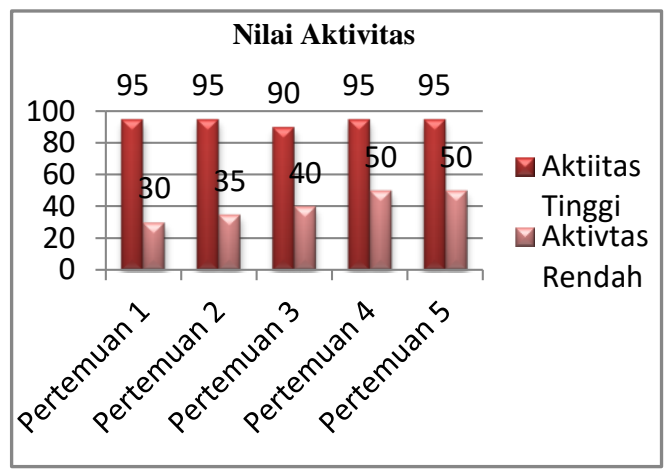

Gambar 2. Diagram Aktivitas Siswa 
Berdasarkan pengambilan data awal yatu uji normalitas awal menggunakan nilai pretest diperoleh $L 0=0,0859$ dengan $n=30$ dan taraf nyata $\alpha=0,05$ dari daftar nilai kritis Ldidapat Ltabel $=0,161$. Karena LO $<$ Ltabel yaitu $0,0859<0,161$, maka HO diterima sehingga dapat disimpulkan sampel berasal dari populasi berdistribusi normal.

Untuk uji homogenitas awal diperoleh data jika $\alpha=0,05$ dari daftar distribusi $x 2$ dengan $\mathrm{dk}=(\mathrm{k}-1)=(5-1)=4$ didapat $x_{0,95}^{2}=9,48$ dan didapat $x_{\text {hitung }}^{2}=2,083$. Hal ini berarti $x_{\text {hitung }}^{2}$ $=2,083<x_{0,95}^{2}=9,48$. Sehingga dapat disimpulkan hipotesis $\mathrm{HO}$ diterima. Artinya kelima kelompok dalam satu kelas sampel tersebut mempunyai varians yang sama (homogen).

Pengambilan data akhir mengunakan nilai posttest yaitu untuk uji normalitas akhir diperoleh $L 0=0,1385$ dengan $n=30$ dan taraf nyata $\alpha=0,05$ dari daftar nilai kritis $L$ didapat Ltabel $=0,161$. Karena $\mathrm{LO}<\mathrm{L}_{\text {tabel }}$ yaitu $0,1385<0,161$ maka $\mathrm{H} 0$ diterima sehingga dapat disimpulkan sampel berasal dari populasi berdistribusi normal.

Berdasarkan data hasil penelitian untuk homogenitas varian data akhir didapatkan $\mathrm{F}_{\text {hitung }}$ $=0,625<F_{\text {tabel }}=3,150$. Sehingga dapat disimpulkan bahwa kedua varian tersebut berdistribusi varian yang sama atau homogen.

Berdasarkan pengujian korelasi yag pertama dengan korelasi product moment diperoleh $r_{\text {hitung }}=0,959$ dengan $r_{\text {tabe }} l=0,361$ taraf signifikan $\alpha=5 \%$ dengan $n=30$, sehingga diperoleh $r_{\text {hitung }}>r_{\text {tabel }}$ yaitu $0,921>0,361$. Dengan demikian HO ditolak dan Ha diterima. Dapat disimpulkan bahwa ada korelasi antara aktivitas siswa dengan hasil belajar siswa dengan model Think Pair Share (TPS) berbantu media papontar pada pembelajaran tema daerah tempat tinggalku subtema lingkungan tempat tinggalku kelas IV SDN 05 Kabunan Kabupaten Pemalang.

Untuk uji regresi linear sederhana digunakan untuk menguji pengaruh model Think pair Share (TPS) berbantu media papontar dengan aktivitas belajar siswa. persamaan regresinya adalah $\widehat{Y}=15,89+0,83 X$, artinya bahwa setiap perubahan aktivitas $(X)$ siswa satu satuan maka nilai hasil belajar siswa dengan model TPS berbantu media papontar $(\mathrm{Y})$ akan bertambah sebesar 0,836.

Perhitungan uji keberartian regresi linier sederhana digunakan untuk mengetahui linier antara aktivitas $(\mathrm{X})$ dengan hasil belajar siswa $(\mathrm{Y})$ apakah mempunyai keberartian atau tidak. Berdasakan data yang diperoleh bahwa $\alpha=0,05$ dan $\mathrm{dk}(10,18)$ diperoleh $\mathrm{F}_{\text {tabel }}=2,79$ karena $F_{\text {hitung }}<F_{\text {tabel }}=$ yaitu $1,478<2,79$ maka $H_{0}$ diterima. Jadi kesimpulannya ada hubungan antara aktivitas siswa dengan hasil belajar yang linier.

Uji koefisien regresi linier ini digunakan untuk mengetahui koefisien regresi berarti atau tidak, berdasarkan data hasil penelitian diperoleh $F_{\text {tabel }}=0,361$ sedangkan $F_{\text {hitung }} 0,921$ dengan taraf signifikan $\alpha=5 \%$ dengan $d k=28$, sehingga diperoleh $F_{\text {hitung }}>F_{\text {tabel }}$ yaitu $0,921>0,361$. Dengan demikian $\mathrm{HO}$ ditolak dan Ha diterima (koefisien regresi berarti).

Koefisien determinasi ini digunakan untuk mengetahui seberapa besar pengaruh aktivitas siswa dengan hasil belajar siswa menggunakan model Think Pair Share (TPS). Diperoleh data dari koefisien determinasi sebesar $84,96 \%$ yang artinya pengaruh antara aktivitas siswa dengan hasil belajar menggunakan model Think Pair Share (TPS) sebesar 84,96\% dan 15,04\% dipengaruhi oleh faktor lain yang tidak diteliti dalam penelitian ini.

Uji hipotesis 2 dalam penelitian ini menggunakan uji t dua pihak untuk mengetahui perbedaan hasil belajar berdasarkan aktivitas tinggi dan aktivitas rendah setelah menggunakan model Think Pair Share (TPS) berbantu media papontar untuk siswa kelas IV SDN 05 Kabunan Kabupaten Pemalang. Berdasarkan pengujian uji dua pihak diperoleh bahwa $t_{\text {hitung }}=2,190$ sedangkan $t_{\text {tabel }}=2,048$ dengan $t_{1_{-1 / 2}} \alpha$ dengan taraf signifikan $5 \%$, sehingga $-t_{\text {tabel }}<t_{\text {hitung }}>t_{\text {tabel }}$ atau $-2,048<2,190>2,048$, dengan demikian Ho ditolak dan Ha diterima. Sehingga dapat disimpulkan ada perbedaan siswa yang aktivitasnya tinggi dengan siswa yang aktivitasnya rendah pada pembelajaran tema daerah tempat tinggalku subtema lingkungan tempat tinggalku kelas IV SDN 05 Kabunan Kabupaten Pemalang.

Model Think Pair Sahre (TPS) berbantu media papontar dikatakan dapat mencapai ketuntasan belajar siswa pada pembelajaran tema daerah tempat tinggalku subtema lingkungan tempat tinggalku kelas IV SDN 05 Kabunan apabila nilai rata-rata hasil belajar siswa sekurang-kurangnya mencapai 75\% dari jumlah yang mendapat nilai diatas KKM 75.

Siswa dikatakan tuntas belajar jika mereka mampu menyelesaikan, menguasai kompetensi atau mencapai tujuan pembelajaran. Pada ketuntasan belajar individu dalam penelitian ini dari 30 siswa terdapat 23 siswa yang tuntas dan 7 siswa yang tidak tuntas dalam mencapai KKM. 
Ketuntasan belajar klasikal dikatakan berhasil apabila sekurang-kurangnya $75 \%$ dari hasil belajar siswa mencapai tingkat penguatan yang ditetapkan yaitu 75 . Berdasarkan data hasil penelitian diperoleh ketuntasan belajar klasikal > ketuntasan belajar minimal, $77 \%>75 \%$ maka pembelajaran dikatakan berhasil.

Pada observasi pertemuan pertama siswa diberikan pretest yang berjumlah 25 soal dan siswa tampak bingung dengan adanya pretest tersebut karena materi siswa belum sampai pada tema daerah tempat tinggalku subtema lingkungan tempat tinggalku, sehingga siswa tampak mengerjakan dengan sepengetahuan siswa saja. Kemudian pada saat masuk pembelajaran siswa terlihat bersemangat karena dalam pembelajaran yang peneliti sampaikan menggunakan model TPS berbantu media papontar sehingga dalam pembelajaran siswa bisa sambil bermain. Aktivitas siswa pada hari pertama bisa dikatakan masih rendah karena siswa mungkin masih bingung dan masih belum percaya diri untuk menyampaikan pendapatnya. Pada hari kedua pembelajaran, peneliti menggunakan proyektor untuk menampilkan materi yang akan disampaikan. Siswa terlihat memperhatikan dan mengamati dari materi yang peneliti sampaikan menggunakan proyektor didepan kelas, sehingga semangat siswa untuk belajar bertambah. Pada hari itu juga bisa dikatakan siswa sudah bisa memahami langkah model TPS yaitu dibuktikan dengan siswa berdiskusi dengan teman satu bangkunya dengan baik, dan disampaikan di depan kelas dengan percaya diri.

Pada hari ketiga pembelajaran berjalan semakin baik, aktivitas siswa juga sudah mulai terlihat yaitu ketika guru bertanya siswa sudah bisa langsung menjawab dan pada saat media papontar dimainkan siswa terlibat langsung aktif dalam permainan tersebut. Untuk hari keempat dan kelima siswa sudah memahami benar tentang langkah model TPS yaitu siswa berdiskusi dengan baik, siswa yang tadinya masih suka bercanda dengan temanya ketika berdiskusi sudah mulai ikut berpartisipasi dalam kelompok. Siswa juga terlihat sangat senang dan semangat dalam belajar apalagi dengan adanya media papontar yang dapat menambah pemahaman materi bagi siswa. Dan siswa merasa cara belajar mereka santai sambil bermain tetapi tetap dapat fokus dalam materi yang dismapaikan peneliti. Setelah pemberian perlakuan sampai 5 kali pertemuan kemudian siswa di berikan posttest. Peneliti membagikan posttest kepada siswa yang berjumlah 25 soal kemudian siswa mengerjakan soal posttest dengan tenang, mereka terlihat seperti sudah menguasai materi yang sudah diajarkan. Sehingga siswa mengerjakan posttest sendiri-sendiri dengan kemampuan mereka masing-masing. Hal ini dibuktikan dengan nilai rata-rata pretest dan posttest yaitu rata-rata pretest 61,33 dan posttest 78,93 sehingga dapat dikatakan pembelajaran dengan model Think Pair Share (TPS) berbantu media papontar pada pembelajaran tema daerah tempat tinggalku subtema lingkungan tempat tinggalku kelas IV SDN 05 Kabunan Pemalang dikatakan berhasil.

\section{Simpulan dan Saran}

Berdasarkan penelitian yang telah dilakukan maka :1) Pada hasil uji korelasi product moment diperoleh hasil $r_{\text {hitung }}>r_{\text {tabel }}$ atau 0,921 $>0,361$ menunjukkan bahwa ada korelasi antara model Think Pair Share (TPS) berbantu media papontar dengan aktivitas belajar siswa pada tema daerah tempat tinggalku subtema lingkungan tempat tinggalku kelas IV SDN 05 Kabunan Kabupaten Pemalang, 2) Pada hasil uji t diperoleh hasil $t_{\text {hitung }}>t_{\text {tabel }}$ yaitu 2,190 $>2,048$, HO ditolak dan Ha diterima yang artinya ada perbedaan hasil belajar antara siswa yang aktivitasnya tinggi dengan siswa yang aktivitasnya rendah setelah mendapat pembelajaran dengan model Think Pair Share (TPS) berbantu media papontar.

Berdasarkan hasil penelitian yang diperoleh, agar proses pembelajaran dapat memberikan hasil yang maksimal maka saran yang disampaikan khsususnya bagi guru dalam pembelaran dengan menggunakan model Think Pair Share (TPS) berbantu media papotar diharapkan mampu sebagai fasilitator, motivator dan inovator dalam pembelajaran, agar pembelajaran menjadi efektif dan siswa tidak mudah bosan. Selain itu guru juga harus lebih kreatif dalam memilih model pembelajaran yang tepat dan disesuaikan dengan materi dan karakteristik siswa agar hasl belajar siswa leih baik.

Bagi pembaca, model pembelaran Think Pair share (TPS) berbantu mdia papontar yang direkomendasikan oleh penulis agar tetap dapat diterapkan pada pembelajaran karena model pembelajaran ini dapat menciptakan pembelajaran yang menyenangkan dimana siswa dapat bertukar pendapat dengan teman satu bangkunya dan berbagi kepada teman yang lainnya. 


\section{Daftar Pustaka}

Anggia, Tiara. 2015. Pengaruh Profesionalisme Guru Dan Motivasi Kerja Terhadap Kinerja Guru Ekonomi Sma Se-Kota Malang . Jurnal Promosi Jurnal Pendidikan Ekonomi Um Metro

Arikunto, Suharsimi. 2010. Prosedur Penelitian. Jakarta: Rineka Cipta.

Arsyad, Azhar. 2016. Media Pembelajaran. Jakarta: PT RajaGrafindo Persada.

Daryanto. 2010. Belajar dan Mengajar. Bandung: CV Yrama Widya.

Depdiknas. 2003. Undang-undang RI No. 20 Tahun 2003 Tentang Sistem Pendidikan Nasional. Jakarta: Depdiknas.

Ertikanto, Chandra. 2016. Teori Belajar dan Pembelajaran. Yogyakarta: Media Akademi.

Megawati, Priarti . 2012. Meretas Permasalahan Pendidikan Di Indonesia . Jurnal Formatif 2(3): 227-234 ISSN: 2088-351X

Mufidah, Efendi dan Teri, 2013. Penerapan kooperatif tipe TPS untuk meningkatkan aktivitas belajar siswa pada pokok bahasan matriks. Jurnal Pendidikan Matematika STKIP PGRI Sidoarjo, Volume 1.

Parwati, Ni Nyoman, dkk. 2018. Belajar dan Pembelajaran. Depok: PT RajaGrafindo Persada.

Sardiman. 2014. Interaksi dan Motivasi Belajar Mengajar. Jakarta: PT RajaGrafindo Persada.

Shabir, M. 2015. Kedudukan Guru Sebagai Pendidik . Jurnal Auladuna, Vol. 2 No. 2 Desember 2015: 221-232

Sugiyono. 2016. Metode Penelitian Kuantitatif, Kualitatif dan R\&D. Bandung. Alfabeta.

Susanti, Tampubolon dan Marli, 2017. Pengaruh model pembelajaran Think Pair Share terhadap hasil belajar siswa di kelas IV Sekolah Dasar. Jurnal Pendidikan dan Pembelajaran. PGSD FKIP Universitas Tanjungpura, Pontianak. Volume 6.

Susanto, Ahmad. 2016. Teori Belajar dan Pembelajaran Di Sekolah Dasar. Jakarta: Kencana

Theana, Oka Harmas, Ary Susatyo Nugroho dan Eka Sari Setaningsih, 2017. Keefektifan Model Pemelajaran Time Token Terhadap Hasil Belajar Subtema Keseimbangan Ekosistem Siwa Kelas V SD. Jurnal Sekolah (JS). PPSD FIP Universias Medan. Vol. 2, No. (1), hal :67-71. 